\title{
Exploring the contrasting seasonal strategies of two crenic macroalgae
}

\author{
Marco Cantonati*1, Daniel Spitale ${ }^{1}$, Alessia $\mathrm{Scalfi}^{1} \&$ Graziano Guella $^{2}$
}

\author{
${ }^{1}$ Museo delle Scienze - MUSE, Limnology and Phycology Section, Corso del Lavoro e della Scienza 3, Trento, \\ Italy; *Corresponding author mail \\ ${ }^{2}$ University of Trento, Department of Physics, Bioorganic Chemistry Lab., Italy
}

\begin{abstract}
Most studies on springs assumed stability, and reduced seasonal changes in the biota. We focused on two macroalgae (the rhodophyte Hildenbrandia rivularis and the chrysophyte Hydrurus foetidus) to unveil their seasonal-development patterns in springs. H. rivularis cover remained virtually constant throughout the year, although seasonal fluctuations in ecophysiological parameters were detected. The most important determinant of seasonal changes in $H$. rivularis was shown to be the complex interplay between solar radiation (day length) and shading. Negative cross-correlation between $\mathrm{Chl}-a$ and shading was found to be significant but with a time lag. H. foetidus seasonal changes were evident both at the macroscopic level and in ecophysiological parameters. Interestingly, it occurred throughout the year in the spring whilst it completely disappeared in summer in a nearby glacial stream. Unexpectedly, variability of ecophysiological parameters (coefficients of variation) was shown to be $15-20 \%$ higher in H. rivularis than in H. foetidus.
\end{abstract}

Key words: seasonality, springs, ecophysiological parameters, freshwater, macroalgae, Hildenbrandia, Hydrurus, groundwater.

\section{INTRODUCTION}

If fed by sufficiently large aquifers, springs are permanent and characterized by daily and seasonal fluctuations of the main environmental parameters (such as temperature and alkalinity) which are relatively-narrow when compared with those of other aquatic habitats (CAntonati et al. 2012a). Spring habitats often host a variety of populations of organisms that can achieve significant abundances (e.g., Stanford et al. 1994), and have considerable importance in maintaining biodiversity, being able to act as true ecological refugia (e.g., ТАХвӧсK et al. 2016) for species that need stable environmental conditions and particularly-clean water. These habitats are however in danger, being highly-fragile and sensitive to human impacts (e.g., Cantonati et al. 2012a). The extraction of water for drinking, energy, and irrigation purposes causes a decrease in the number of near-natural springs. In the Alps, the sources with higher discharge have generally been used for these purposes, even in protected areas where strict regulations should limit their use (CANTONATI et al. 2009, 2012a). For their stability, sources are ideal monitoring sites for detecting changes in environmental characteristics at the local, regional, and global scale. With a view to medium and long-term studies on spring biological communities, it is possible to detect possible signs of change and estimate, as a result, the effects of the possible alteration on the environment (GERECKE et al. 2011).

Sessile benthic algae are the dominant primary producers in the springs of the Alps and in springfed rivers, although lichens, bryophytes, and higher plants are essential components of the flora (Rотт et al. 2006a). Many environmental variables (physical and chemical factors) affect the growth of epilithic algae: light (e.g., HiLl et al. 1995; NeCCHI \& ZuCCHI 2001), temperature (NECCHI \& ZuCCHI 2001), substrate composition and grain size (BuINN et al. 1980), pH (MAURICE et al. 1987), nutrients (ELwood et al. 1981), and current speed and disturbance (Peterson \& Stevenson 1992).

The variation of these factors causes both spatial and temporal fluctuations, that can be substantial, in periphyton composition and biomass. Information on the responses of freshwater macroalgae to these factors are still relatively-scarce (NECCHI \& ZuCCHI 2001). Generally macroalgae have a time sequence (TeAL 1957) and seasonal peaks in biomass occur in spring-fed streams (WARD \& DUfFord 1979; PFISTER 1993; Spitale et al. 2012). WeHr (1981), after studying the seasonality of the attached algae in the North Alouette River (British Columbia, Canada), concluded that major species tended to show evident seasonal de- 
velopment but with long periods of overlap, supporting the river-continuum (VANNOTTE et al. 1980) idea that, in general, species are merely shifting along temporal and spatial axes, while total exclusion is rare.

Hildenbrandia rivularis (Liebm.) J. Agardh is a red alga forming roundish to irregular crustose thalli on stones. The sexual reproduction is not known but the freshwater species produce gemmae, i.e. flattened cylindrical clusters of cells that develop on the surface of the thallus (SHERwood et al. 2002). H. rivularis lives in shaded areas (Bourrelly 1955; NichOLS 1965; StARMach 1969; Ros et al. 1997) in rivers, lakes (SHERwOOD et al. 2002), rocky ravines and springs (BourRELly 1955). It occurs in neutral or weakly alkaline water (StARMACH 1969; SHEATH et al. 1993; Ros et al. 1997; SHEATH 2003) with relatively-high $(>200$ $\mu \mathrm{S} . \mathrm{cm}^{-1}$ ) conductivity (SHEATH et al. 1993 ; Ros et al. 1997; Sherwood \& Sheath 1999). According to GuTOWSKI \& Foerster (2009), it is an epilithic species, thriving often on the flanks and undersides of stones, occurring from oligo- to eutrophic, and from saprobically unaffected to moderately-affected waters (RоTт et al. 1999). According to the German Red List for red and brown algae it is a threatened species (KNAPPE et al. 1996).

The widespread, cold-water, rheobiontic Hydrurus foetidus (VILL.) TREV., although atypical, was recently confirmed by phylognetical analyses to be a chrysophyte, and it is likely to be a complex of homologous or closely related species (KLAVENESS et al. 2011). It is typical of mountain streams (HIEBER et al. 2001; Nicholls \& WujeK 2002; Lindstrøm et al. 2004; RotT et al. 2006). It thrives in fast-flowing rivers across the Alps at all altitudes, and is also widely distributed in rheocrenic springs (CANTONATI et al. 2006). The species is usually well developed during the colder months of the year but disappears in summer with increasing flow (RotT et al. 2000). Some cells swim away, other form cysts, many probably die. Being an $r$ strategist with rapid growth (RoTT et al. 2000), it is able to reach high biomass values in a very short period of time both in spring and autumn (UEHLINGER et al. 1998). One of the dominant factors in determining seasonal changes seems to be temperature (KRISTIANEN 2005): when the water temperature rises above $10{ }^{\circ} \mathrm{C}$ this alga disappears (Nicholls \& WuJEK 2002; KRISTIANEN 2005). The arbuscular thallus has a gelatinous consistence, it is deeply branched, often dark brown. TRAAEN \& LiNDSTROM (1983) report that the species occurs at current velocities $>80 \mathrm{~cm} . \mathrm{s}^{-1}$. Is not inhibited by light, and is not limited by nutrients (RотT et al. 2000). H. foetidus forms a matrix for specific communities of bacterial taxa, and a co-dominance of protozoa and chironomids grow in the living alga (RotT et al. 2006b). According to RotT et al. (1999) and Gutowski \& Foerster (2009), it is characterized by a broad ecological amplitude with respect to both trophism and saprobity.

The overall aim of this paper is to study seaso- nal variations (type and intensity, cover and ecophysiological parameters) of two selected freshwater benthic macroscopic algae, living in stable environments such as spring habitats. The two species of macroalgae studied characterize two important types of sources (rheocrenes with large discharge and small carbonate, veryshaded rheocrenes). We aim at looking for correlations with physical and chemical variables and at comparing the seasonal strategies of the two macroalgae.

\section{Methods}

Study sites. Two springs, dominated by Hildenbrandia rivularis (Tovare) and Hydrurus foetidus (Ponte delle Cambiali, shortly "Cambiali") respectively, were sampled bimonthly for one year (October 2006-October 2007). The main morphological, physical, and chemical characteristics of the two permanent springs in which the study was carried out are reported in Table 1. Ponte delle Cambiali spring is located within the Adamello-Brenta Nature Park (south-eastern Alps), at the top of the Genova Valley, whilst Tovare spring is located close to the north-eastern limit of this protected area. Cambiali flowing spring (= rheocrene) emerges on crystalline rocks (tonalite) in the Adamello batholith. H. foetidus is the dominant macroalga while the most common cyanobacteria are Tapinothrix janthina (BORNET et FLAHAULT) BohUnicKÁ et J.R.Johansen, Microcoleus favosus (Gomont) Strunecky, Komárek et J.R.Johansen, Schizothrix tinctoria Gomont ex Gomont, and Phormidium retzii (Agardh) GoMONT ex Gomont. The ecomorphology of the source underwent strong changes after works in summer 2005. The local municipality decided to tap the source for drinking purposes and built an intake. The works have greatly changed the environment. It was, however, possible to structure overflow discharges in such a way as to constitute a secondary residual spring habitat. The large discharge of Ponte delle Cambiali spring (Table 1) makes sure that there is always overflow water (generally in substantial quantities even during periods of use of the water intake). The water now flows out of pipes located downstream of the original emergence site, and it is here that the present study was carried out.

Tovare rheocrenic spring emerges in the Brenta mountain range (Western Dolomites), on carbonate substratum. The red alga $H$. rivularis colonizes most of the lithic substratum, although it has to compete for space with the mosses Amblystegium tenax (Hedw.) Jens and Rhynchostegium confertum (Dicks.) Schimp. (DS unpublished data) and with the lichens Verrucaria eleomelaena (A. MASSAL.) ARNOLD and $V$. rheitrophila ZsCHACKE (Nascimbene personal com.). Verrucaria rheitrophila is known to be typically associated with Hildenbrandia rivularis (ORANGE 2000). Small blooms of the diatoms Odontidium hyemale (Rотн) KÜTZING and Odontidium mesodon (EHrEns.) KüTZING were occasionally noted. The diatom Cocconeis lineata EHRENBERG was frequently noted thriving on talli of $H$. rivularis. C. lineata is a typical epiphyte on rhodophytes (CAZAUBON 1989).

Morphological, physical, and chemical parameters measured in the field and laboratory. The two study springs had already been characterized and considered in the frame of the CRENODAT Project, and Ponte delle Cambiali spring is a long-term monitoring site (GERECKE et al. 2011). Mor- 
phological, physical, and chemical variables were assessed and measured following CRENODAT methodology (CANTONATI et al. 2012b).

Physical parameters were measured using the Hydrolab Quanta multiprobe. Discharge was measured with a graduated vessel and chronometer or by measuring current velocity along a transect with a Flowtracker - Sontek current meter. Shading conditions were documented by taking digital images perpendicularly to the site of emergence, and analysing images with the UTHSCSA Image Tool.

Total solar radiation was measured by the meteorological station of Caldes (distant only a few km from Tovare spring) and downloaded from www.meteotrentino.it. Weekly averages were calculated for the whole year considered.

Field work on the two macroalgae. The spring area in which Hildenbrandia rivularis was present was divided into four zones with distinct environmental characteristics, to highlight possible differences among microhabitats. To estimate the growth of thalli a visual survey of covers was carried out. A pebble / small boulder was collected from each zone and photographed every season. The repositioning of the stone into the pool after the photograph was carried out carefully so as not to make any changes to the microclimate. For the calculation of the Dry Weight (D.W.) and of Loss On Ignition (L.O.I.) organic matter, H. rivularis samples were taken from areas of known surface $\left(1 \mathrm{~cm}^{2}\right)$ using a plastic frame $1 \times 1 \mathrm{~cm}$ and a cutter. In each zone five stones were taken and from them a sample of $H$. rivularis corresponding to an area of $5 \mathrm{~cm}^{2}$ was obtained. Samples were fixed with a few drops of formaldehyde (36\%). For the estimation of photosynthetic pigments -chlorophyll- $a(\mathrm{Chl}-a)$ and pheophytin (pheo)-, similar samples were taken close to those for D.W. and L.O.I. (a sample of $5 \mathrm{~cm}^{2}$ from each zone). Before sam- pling, thalli were cleaned from epiphytes with cotton wool soaked in spring water. The material was filtered directly in the field, using a manual vacuum pump and glass fibre filters (Whatman GF/C). Filters folded and wrapped in aluminum foil were kept in the dark and in the freezer $\left(-20^{\circ} \mathrm{C}\right)$. At each sampling, also a qualitative sample of $H$. rivularis was taken for observation under the microscope.

At each Hydrurus foetidus sampling, an estimate of the percent cover was made over an area of $1 \mathrm{~m}^{2}$, and the overall appearance of thalli was documented with photos. For the calculation of the dry weight and of the L.O.I. three $H$. foetidus samples were collected from stones from three areas of known surface $\left(13.85 \mathrm{~cm}^{2}\right)$ using a template $($ diameter $=$ $4.2 \mathrm{~cm}$ ) and a cutter. For the analysis of photosynthetic pigments - Chl $-a$ and fucoxanthin (fucox) - three samples were taken in the vicinity of those considered for the dry weight and the L.O.I. Samples for D.W. and L.O.I. were fixed with a few drops of formaldehyde (36\%), and those for the pigments with absolute ethanol.

Lab work on the two macroalgae. For each $H$. rivularis sampling the following morphological characteristics were examined: number of cells per filament, height of the filament, diameter and height of the cells of the erected filament, height of the basal layer. Thirty measurements per character were taken (SHERWOOD \& SHEATH 2003). The occurrence of false branching, and the possible presence of gemmae were noted as well. All measurements were made under an optical microscope (Zeiss Axioskop 2). For D.W. and L.O.I., the material fixed in the field was subjected to three cycles of centrifugation at $2000 \mathrm{rpm}$ for $15 \mathrm{~min}$ to remove most of the preservative added. The material was placed in previouslycalibrated aluminum crucibles, and was put for $24 \mathrm{~h}$ at 105 ${ }^{\circ} \mathrm{C}$ in an oven with forced ventilation (Binder Mod. FD53).

Table 1. Main morphological characteristics and seasonal changes in the physical and chemical factors in the two springs in which the study was carried out. The values reported for the Tovare Spring are averages of the values recorded in the four zones considered.

\begin{tabular}{|c|c|c|c|c|c|c|c|c|c|c|c|c|c|c|}
\hline & \multicolumn{7}{|c|}{ Tovare Spring (H. rivularis) } & \multicolumn{7}{|c|}{ Cambiali Spring (H. foetidus) } \\
\hline & \multicolumn{7}{|c|}{$\begin{array}{l}\text { GPS: E } 10^{\circ} 58^{`} 11,1^{\prime \prime} ; \mathrm{N} 46^{\circ} 22^{`} 28,0^{\prime c} \text {. Elevation: } 679 \mathrm{~m} \\
\text { a.s.l. Aspect: } \mathrm{N}\end{array}$} & \multicolumn{7}{|c|}{$\begin{array}{l}\text { GPS: E } 10^{\circ} 35^{`} 35,5^{\prime} \text {; } \mathrm{N} 46^{\circ} 11^{`} 52,4^{\prime} \text { “. Elevation: } \\
1665 \text { m a.s.1. Aspect: } \mathrm{S}\end{array}$} \\
\hline & $\begin{array}{r}\text { Oct- } \\
06\end{array}$ & $\begin{array}{r}\text { Dec- } \\
06\end{array}$ & $\begin{array}{r}\text { feb- } \\
07\end{array}$ & $\begin{array}{r}\text { apr- } \\
07\end{array}$ & $\begin{array}{r}\text { Jun- } \\
07\end{array}$ & $\begin{array}{r}\text { Aug- } \\
07\end{array}$ & $\begin{array}{r}\text { Oct- } \\
07\end{array}$ & $\begin{array}{r}\text { Oct- } \\
06\end{array}$ & $\begin{array}{r}\text { nov- } \\
06\end{array}$ & $\begin{array}{r}\text { Jan- } \\
07\end{array}$ & $\begin{array}{r}\text { May- } \\
07\end{array}$ & $\begin{array}{r}\text { Jun- } \\
07\end{array}$ & $\begin{array}{r}\text { Aug- } \\
07\end{array}$ & $\begin{array}{r}\text { Oct- } \\
07\end{array}$ \\
\hline $\begin{array}{l}\text { Current } \\
\text { velocity } \\
\left(\mathrm{cm} . \mathrm{s}^{-1}\right)\end{array}$ & 33 & 29 & 28 & 33 & 36 & 40 & 27 & 106 & 61 & 42 & 62 & 82 & 124 & 78 \\
\hline $\begin{array}{l}\text { Discharge } \\
\left(1 . \mathrm{s}^{-1}\right)\end{array}$ & 6 & 15 & 9 & 10 & 9 & 13.5 & 10.5 & 85 & 64.2 & 38.5 & 75 & 95 & 150 & 80 \\
\hline $\begin{array}{l}\text { Shading } \\
(\%)\end{array}$ & & 44 & 37 & 51 & 88 & 92 & 66 & 0 & 0 & 0 & 0 & 0 & 0 & 0 \\
\hline $\begin{array}{l}\text { Temperatu- } \\
\text { re }\left({ }^{\circ} \mathrm{C}\right)\end{array}$ & 8.7 & 8.7 & 8.7 & 8.8 & 8.7 & 8.7 & 8.9 & 6.3 & 6.2 & 6.7 & 5.9 & 7.2 & 6.2 & 6.5 \\
\hline $\begin{array}{l}\text { Conduc- } \\
\text { tivity } \\
\left(\mu \mathrm{S} . \mathrm{cm}^{-1}\right)\end{array}$ & 316 & 315 & 319 & 316 & 312 & 316 & 296 & 34 & 35 & 43 & 33 & 27 & 33 & 32 \\
\hline $\mathrm{pH}$ & 7.3 & 8.4 & 8.5 & 7.8 & 8.9 & 8 & 7.8 & 6.7 & 7 & 7 & 6.3 & 7.1 & 7.7 & 7.8 \\
\hline $\begin{array}{l}\mathrm{N}-\mathrm{NO}_{3} \\
\left(\mu \mathrm{g} .1^{-1}\right)\end{array}$ & 277 & & & & & & & 470 & & & & & & \\
\hline TP $\left(\mu \mathrm{g} .1^{-1}\right)$ & 5 & & & & & & & 3 & & & & & & \\
\hline
\end{tabular}


After weighing, the sample was placed for another $4 \mathrm{~h}$ at 550 ${ }^{\circ} \mathrm{C}$ in a muffle furnace (Gefran $1001 \mathrm{Mod}$. ZB), and was then weighed again (WestlaKe 1971). For the analysis of $\mathrm{H}$. foetidus (fucox and Chl-a) and H. rivularis (Chl- $a$ and pheo) photosynthetic pigments, the fresh samples were immersed in absolute ethanol. The concentration of Chl- $a$ and pheo was estimated by spectrophotometric analysis (LORENZEN 1967) with an acidification step (MARKER et al. 1980). The analysis of fucox was performed through a selective and sensitive methodology, mainly based on reversed-phase HPLC coupled both to UV photodiode array detection and to atmospheric pressure mass spectrometric techniques (HPLCDAD-APIMS) (FrasSANITO et al. 2005).

Data analysis. The seasonal averages of the ecophysiological parameters considered for $H$. foetidus and $H$. rivularis were compared by analysis of variance (ANOVA), one-way and factorial, testing hypotheses with Fisher (F) tests with the usual threshold value of 0.05 . To compare the dispersions of the variables, the coefficient of variation $[\mathrm{CV}=(\mathrm{SD} \times 100) /$ mean] was calculated. It $>\mathrm{S}$ a relative measure of dispersion, and thus very useful to compare the variability of two or more groups that have very different averages or when the data are expressed in very different units of measurement. The coefficient of variation is a pure number unrelated to any measurement scale and to the central tendency of the phenomenon studied.

For the study of the Hildenbrandia rivularis population we used a factorial ANOVA, in which the two factors correspond to the zone and to the sampling date, while the response variables are $\mathrm{Chl}-a$, pheo, D.W., and L.O.I. For the characterization of the four sampling zones and of the twomonth periods according to abiotic factors (current speed, and shading) a one-way ANOVA was used. To find significant correlations between abiotic and biotic variables for $H$. rivularis, multiple linear and polynomial (second degree) regressions were applied. A cross correlation was used to detect a delay (lag) between two similar trends. The technique suggests a value for this lag, in a way such as to maximize the correlation between the two variables.

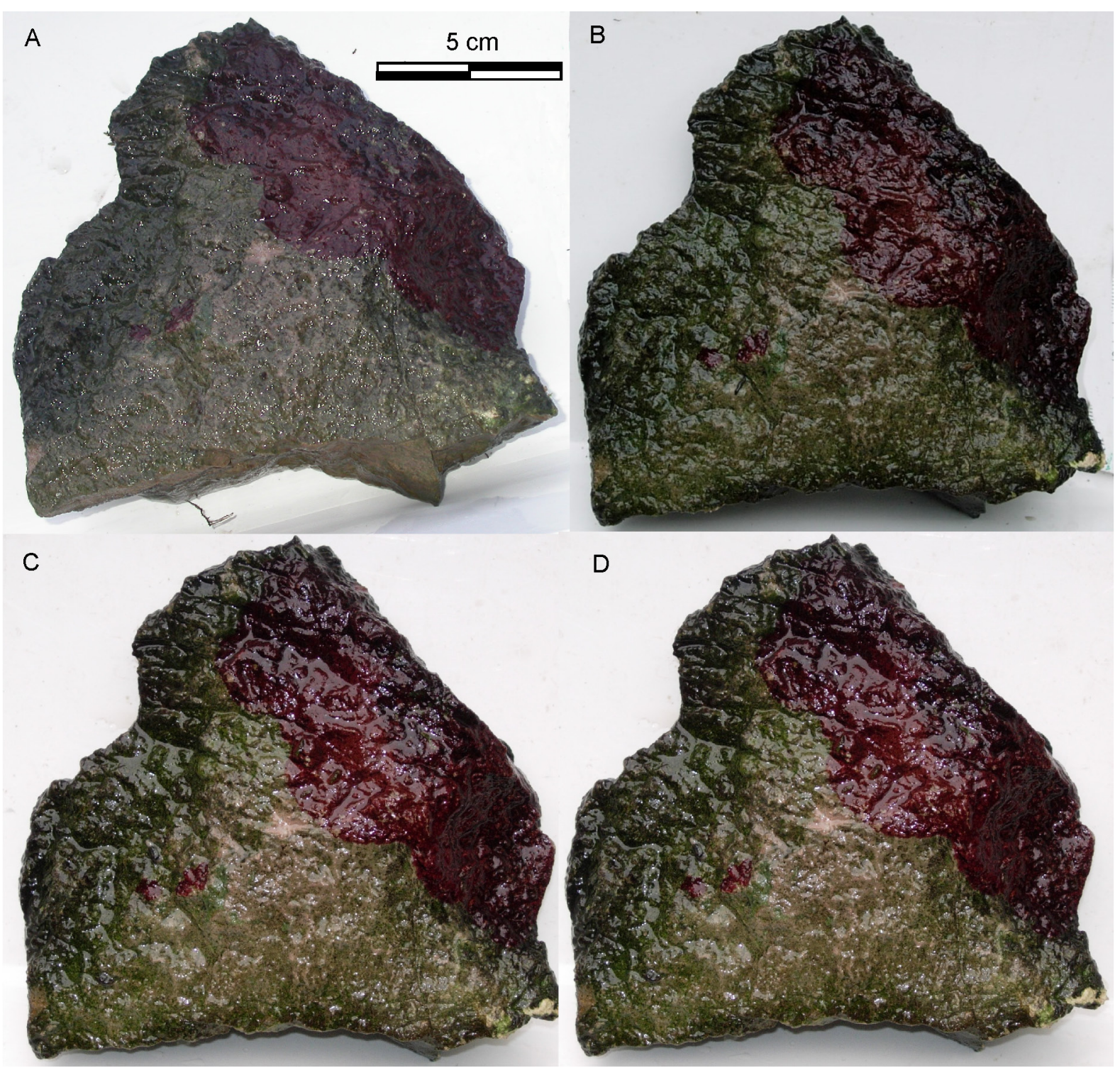

Fig. 1. Photos showing the absence of variation in the extension of a marked thallus (positioned in the Tovare Spring) of the red alga Hildenbrandia rivularis over the one-year study period (October 2006 to October 2007). 
To avoid a depletion of the habitat and excessive disturbance to the $H$. rivularis population, we chose to take three replicate samples only on the first sampling date (October $10^{\text {th }}$ 2007), and the coefficient of variation was calculated on the data of the replicate measurements for each ecophysiological parameter considered. The percentage value of the coefficient of variation was used as an estimate of the error of the data collected, assuming an almost constant and very small intra-zone variation. Some studies on freshwater phytobenthos (e.g., KING et al. 2006) assume that the spatial microvariability within a site is very small and such as to allow for cumulative samples.

For the study of $H$. foetidus, one-way ANOVAs, in which the independent variable is the sampling date and the dependent variables are the ecophysiological parameters considered, were used.

\section{Results}

Morphological, physical, and chemical characteristics of the study springs. Table 1 reports the values of the main physical and chemical factors measured during the study period in the two springs. The values do not undergo major fluctuations throughout the year. In both sources the water is always close to saturation in oxygen. In both sources the flow rates show a peak in summer (in conjunction with the period of the melting of snow and ice), and, in the case of the Tovare Spring, one in December (perhaps due to a short period with above-average temperatures). Current velocity showed a trend similar to the discharge in the Cambiali Spring whilst in the Tovare Spring the values of current speed vary in the four zones. Cambiali Spring was almost completely exposed for the whole year while the Tovare Spring percent shading varied among seasons and zones. For the Tovare Spring, one-way ANOVAs revealed that the four zones differed in a statistically significant way for current velocity $(\mathrm{F}=14.4, \mathrm{P}=$ 0.00003 ) (significant differences between the zones for shading were not found) whilst the two-month periods for shading $(F=9.3, P=0.0003)$. Shading was highest in the summer months, when the growth of forest vegetation and undergrowth peaked while it was minimal in the winter months.

\section{Macroscopic cover of $\boldsymbol{H}$. rivularis and $\boldsymbol{H}$. foetidus} Visual (photographical) assessments of Hildenbrandia rivularis in the Tovare spring confirmed substantial stability in the covers of $H$. rivularis in each zone (as shown, e.g., by the images of a thallus taken from zone 1, Fig. 1).

Cover assessment of Hydrurus foetidus in the Cambiali Spring showed some seasonal fluctuation (Fig. 2). The highest covers, approx. 90\%, were observed in mid-November and at the end of June. foetidus, as well as the Chl- $a$ and fucox varied significantly over time: there was therefore a clear seasonality (Table 2). The highest values of biomass (D.W. and L.O.I.) were recorded in late June, and the lowest in January. Even Chl- $a$ reached the highest value at the end of June, while fucox in early May. The lowest values were recorded in August for both parameters (Fig. 3).

\section{Environmental determinants of seasonal changes in} ecophysiological parameters

Considering the abiotic variables current velocity and shading, which differentiate respectively the four zones and the seasons, we tested the existence of a significant relationship with the biotic variables considered (D.W., L.O.I., Chl-a, and pheo.). Linear relationships between the biotic and abiotic variables could not be found applying multiple regressions (Table 3). Thus $H$. rivularis does not vary linearly in statistically significant way with respect either to current speed or shading. Consequently we looked for non-linear relationships among variables. A single quadratic (second degree polynomial) significant relationship between Chl- $a$ and shading could be found (Wald $=7, \mathrm{P}=0.008$ ).

Considering the range of values of weekly averages of irradiation over the station of Caldes, there was a good relationship between the biotic and abiotic parameters. Chl- $a$ increased with total radiation and shading in the first section. When the shading was too high, Chl- $a$ decreased (quadratic relationship), even though the values of total radiation remained high (Fig. 4). We tried to give a statistical value to this trend by means of cross-correlation. This technique suggested a lag (delay) between the two variables (Chl- $a$ and shading) of three time steps (= dates). With this lag value, Chl $-a$ and shading are negatively correlated with a $\mathrm{P}$ bordering significance (0.08).

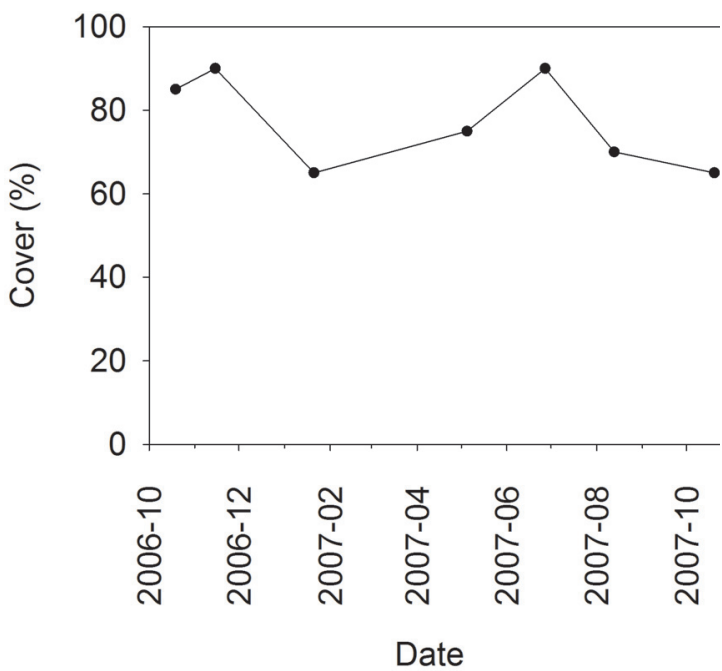

Fig 2. Per cent cover of the chrysophyte Hydrurus foetidus in the Cambiali Spring from October 2006 to October 2007. 
Hildenbrandia rivularis
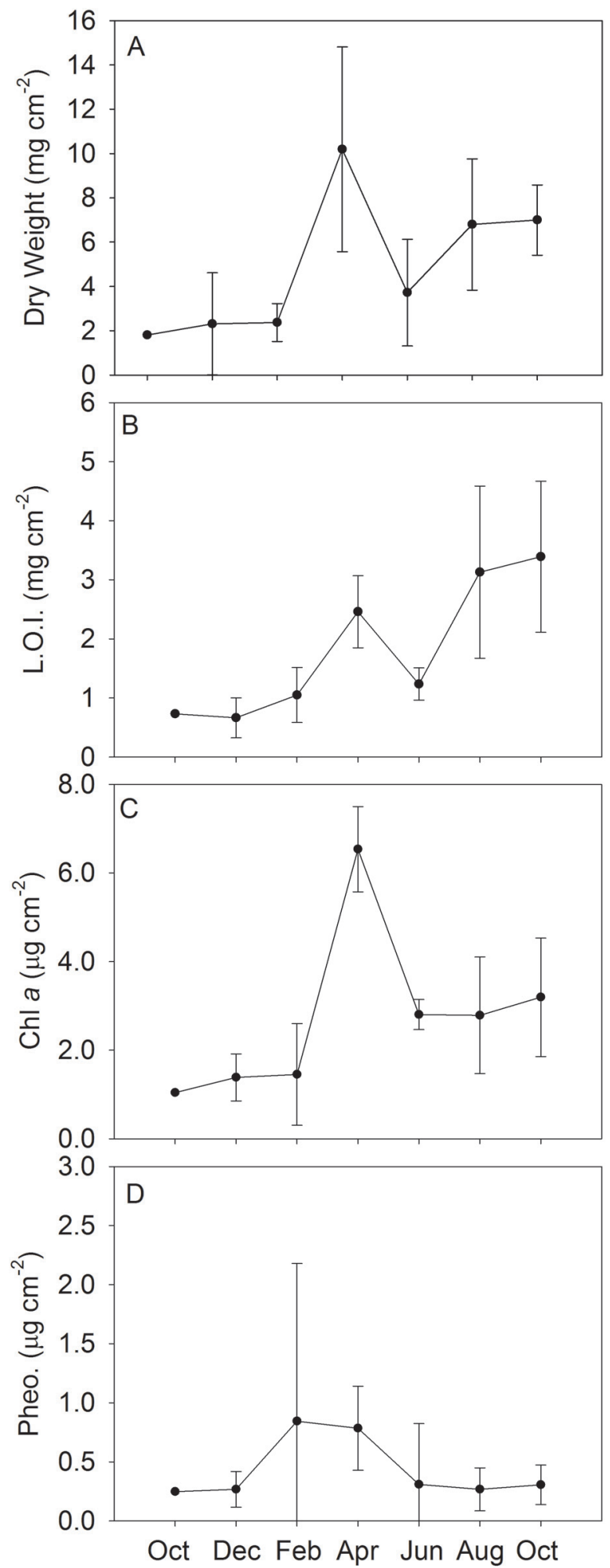

Hydrurus foetidus
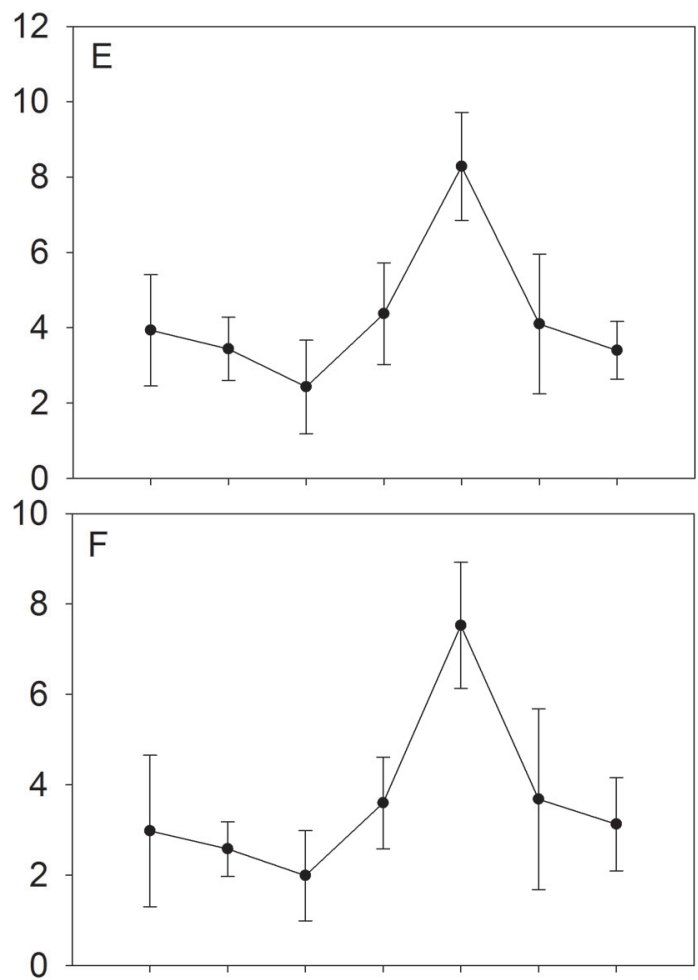

100
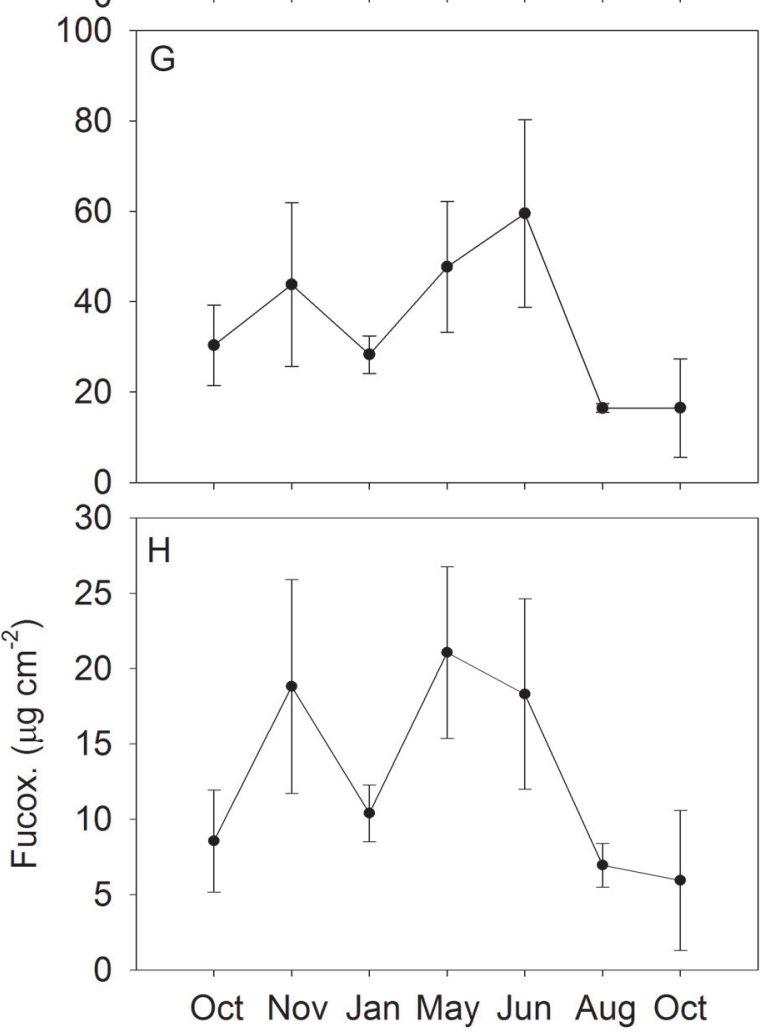

Fig.3.Seasonalchangesindryweight(A-E),L.O.I.(LossOnIgnition)organicmatter(B-F), Chlorophyll- $a$ (C-G), andfucoxanthin(D-H)forHildenbrandiarivularis (A-D)andHydrurusfoetidus (E-H). For H.rivularis thevaluesreportedaretheaveragesofmeasurementscarried outinthefourzones. 
Coefficients of variation of the ecophysiological parameters considered for the two macroalgae

Considering the coefficients of variation of Chl- $a$, D.W., and L.O.I., H. rivularis showed a variability which was $10-20 \%$ greater than that of $H$. foetidus. In a contrasting way to macroscopic observations, ecophysiological parameters were less stable for $H$. rivularis than for $H$. foetidus (Table 4).

\section{Discussion}

The obvious and pronounced seasonality of Hydrurus foetidus was also demonstrated through the analysis of ecophysiological parameters. In particular, the season of the year more favourable for $H$. foetidus in the spring studied is found to be the end of spring-early summer. The alga, however, never disappears in the spring environment. It colonizes the epilithic substratum continuously throughout the year. This is an important difference from what observed by RoTT et al. (2000) in glacial streams, where H. foetidus tends to disappear when discharge reaches the maximum because of snow and ice melting during the summer, and then regenerates to September-October and persists during the colder months of the year. Massive $H$. foet $i$ $d u s$ growths of short duration are in fact typical of glacial streams (UeHLINGER et al. 1998; RotT et al. 2006a). From this literature information it is thus apparent that the seasonality of $H$. foetidus in the spring environment is much less marked than in mountain streams. This might be explained considering the particular stability of the krenon, which provides particularly balanced conditions for the algal communities. The association of $H$. foetidus with groundwater discharge areas (springs discharging into nearby streams, upwelling sites) was confirmed by recent field studies in mountain and alpine streams and rivers (WYATT et al. 2008; Roy et al. 2011). According to Kristianen (2005), one of the strongest determinants of $H$. foetidus seasonality is temperature. When the water temperature rises above $10^{\circ} \mathrm{C}, H$. foetidus begins to disappear (Nicholls \& WuJEK 2002; KRISTIANEN 2005). The temperatures measured in the spring during our sampling surveys never reached such high values. Another factor that might have influenced the seasonality of $H$. foetidus in our study is the intensity of incident light on the spring, which reaches its maximum right at the end of spring - early summer. According NECCHI \& ZUCCHI (2001), it can be said that, despite recognition of the importance of light and temperature on the growth and distribution of algae in lotic systems, ecophysiological studies are relatively scarce and, in the particular case of red algae, restricted to a few species.

Hildenbrandia rivularis used to be well-known from streams but CANTONATI et al. (2012b) list it as a characteristic species of the spring type "Low-altitude, mostly shaded, $\mathrm{N}$-enriched rheocrenes on carbonate substratum". In Poland it is considered rare and is protected (e.g., JAKUBAS et al. 2014) but its first report in central Poland occurred in a spring head (ŻELAZNAWieczoreK \& ZiUlKiewicz 2008). In our study, the ecophysiological parameters analysed for $H$. rivularis unveiled seasonal fluctuations, although this alga macroscopically appeared to be a constant presence in the spring. Chl $-a$ turned out to be the most explanative parameter. The abiotic factor most important in de-

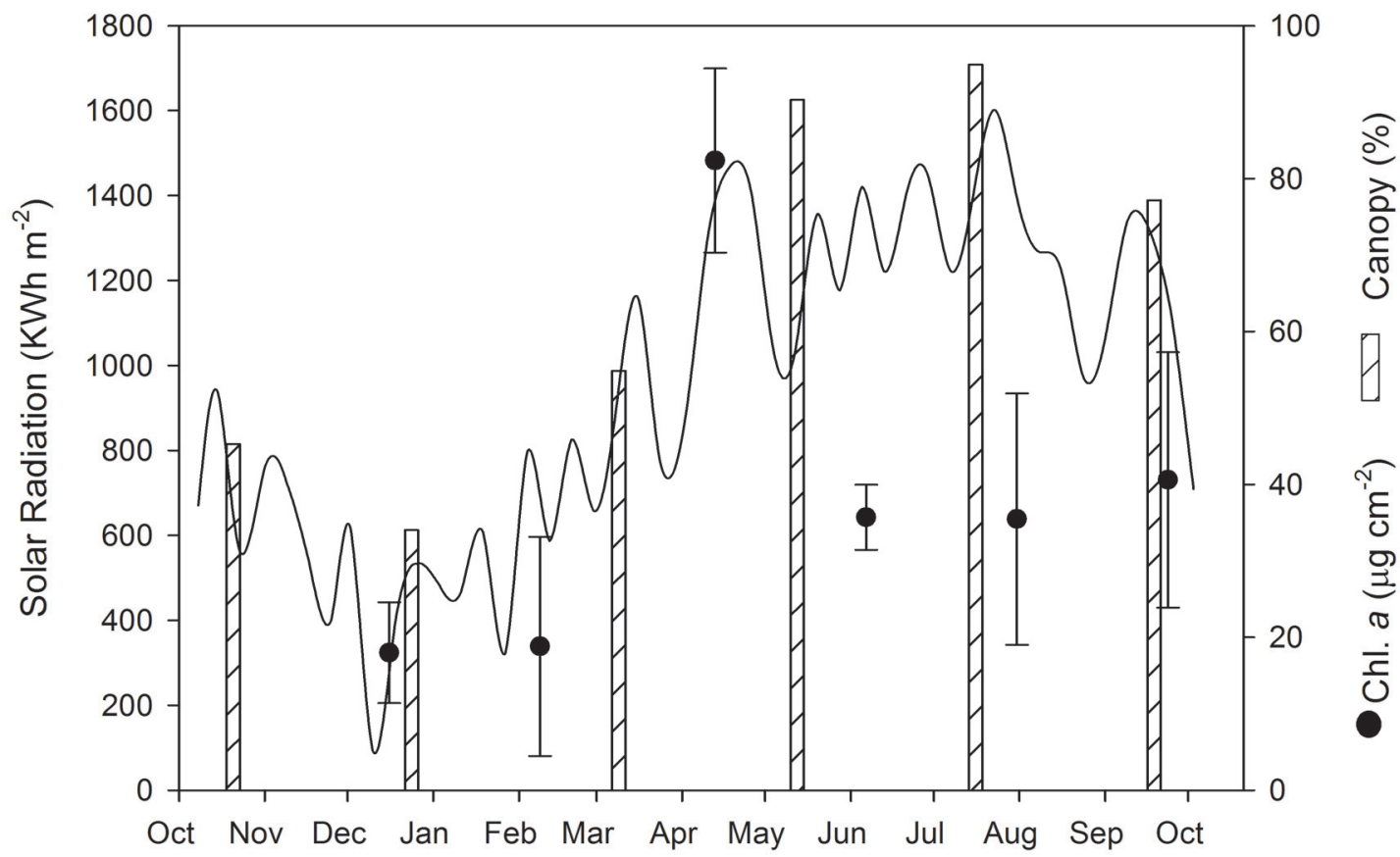

Fig. 4. Tovare Spring (H. rivularis): Total radiation, shading, and chlorophyll-a. 
Table 2. Results of the ANOVA tests carried out to test seasonal changes assessed for the ecophysiological parameters measured for the two species [(D.W.) Dry weight; (L.O.I.) Loss On Ignition organic matter; (Pheo) Pheophytin, (Fucox) Fucoxanthin, (SS) Sums of Squares, (DF) degrees of freedom; (MS) Mean Square, (F) F statistic].

\begin{tabular}{|c|c|c|c|c|c|c|c|c|c|c|}
\hline \multicolumn{6}{|c|}{ Hildenbrandia rivularis } & \multicolumn{5}{|c|}{ Hydrurus foetidus } \\
\hline D.W. & SS & DF & MS & $\mathrm{F}$ & $P$ & SS & $\mathrm{DF}$ & MS & $\mathrm{F}$ & $\mathrm{P}$ \\
\hline Intercept & 1794.6 & 1 & 1794.6 & 218.3 & 0.000 & 384.2 & 1 & 384.2 & 217.9 & 0.0000 \\
\hline data & 367.9 & 5 & 73.6 & 9.0 & 0.000 & 63.3 & 6 & 10.6 & 6.0 & 0.0028 \\
\hline Error & 542.5 & 66 & 8.2 & & & 24.7 & 14 & 1.8 & & \\
\hline L.O.I. & SS & DF & MS & $\mathrm{F}$ & $\mathrm{P}$ & SS & $\mathrm{DF}$ & MS & $\mathrm{F}$ & $\mathrm{P}$ \\
\hline Intercept & 283.0 & 1 & 283.0 & 307.1 & 0.000 & 278.2 & 1 & 278.2 & 159.7 & 0.0000 \\
\hline data & 88.1 & 5 & 17.6 & 19.1 & 0.000 & 58.9 & 6 & 9.8 & 5.6 & 0.0037 \\
\hline Error & 60.8 & 66 & 0.9 & & & 24.4 & 14 & 1.7 & & \\
\hline Chl- $a$ & SS & DF & MS & $\mathrm{F}$ & $\mathrm{P}$ & SS & $\mathrm{DF}$ & MS & $\mathrm{F}$ & $\mathrm{P}$ \\
\hline Intercept & 618.0 & 1 & 618.0 & 651.4 & 0.000 & 23521.1 & 1 & 23521.1 & 133.7 & 0.0000 \\
\hline data & 212.7 & 5 & 42.5 & 44.8 & 0.000 & 4758.4 & 6 & 793.1 & 4.5 & 0.0110 \\
\hline Error & 62.6 & 66 & 0.9 & & & 2287.8 & 13 & 176.0 & & \\
\hline Pheo/Fucox & SS & DF & MS & $\mathrm{F}$ & $P$ & SS & DF & MS & F & $\mathrm{P}$ \\
\hline Intercept & 13.0 & 1 & 13.0 & 43.9 & 0.000 & 3472.1 & 1 & 3472.1 & 150.5 & 0.0000 \\
\hline data & 3.7 & 5 & 0.7 & 2.5 & 0.038 & 719.1 & 6 & 119.9 & 5.2 & 0.0053 \\
\hline Error & 19.6 & 66 & 0.3 & & & 322.9 & 14 & 23.1 & & \\
\hline
\end{tabular}

termining the seasonality of Chl- $a$ appeared to be the amount of light that reached the thalli of $H$. rivularis. It depends on the degree of insolation and on total shading created by the vegetation cover. In various studies (e.g., Sheath \& Burkholder 1985), it was noted that the available light and the effect of shading influence the composition and abundance of macroalgae communities. The light regime, understood as a range of fluctuations, intensity, quality, and photoperiod, affect the seasonality of freshwater red algae (SHEATH \& BurKHOLder 1985). Like many red algae, $H$. rivularis is often found in shaded habitats / microhabitats, being adapted to survive in low-light (BOURRELly 1955; STARMACH 1969; Ros et al. 1997), and showing a preference for low-light regimes (KREMER 1983; SABATER et al. 1989; Sheath \& Hambrook 1990; Leukart \& Hanelt 1995; NeCchi \& Zucchi 2001; Eloranta \& Kwandrans 2004; Cantonati et al. 2012b; Ceschin et al. 2013). Our study showed that when shading is too high, Chl- $a$ values were lower than those measured in the presence of more abundant light. Shading and Chl $-a$ are negatively correlated and reach the maximum correlation with a lag of three steps, probably due to the time required by the alga for physiological adaptation. The relationship between the two variables could be observed both by considering the temporal and the spatial pattern of microhabitats. This result is in agreement with a study by Cox (1990), which ar- gues that in the presence of constant temperature the increase of periphyton $\mathrm{Chl}-a$ is probably due to the increase of insolation. With the arrival of summer, the trees reduce the light input on the site and may explain the decrease in Chl- $a$. With this in mind, it seems that $H$. rivularis survives well in conditions of high shading thanks to a particular adaptation of the species, but it is more productive in the presence of more intense light. This result does not seem to support the observations of SHERwoOd \& SHEATH (1999), who argued that the percentage cover of Hildenbrandia angolensis is negatively correlated with day length, indicating that this species is most abundant during winter months when there are fewer hours of daylight. It is possible that the seasonal growth strategy we have identified for $H$. rivularis is characteristic of spring-habitat-dwelling populations only, while patterns might be different in environments with greater light and nutrient availability, which turn out to be as well colonized by the species (e.g., Gutowski \& Foerster 2009).

The two springs considered for this study were selected because they were those hosting the largest populations of the two macroalgal species to be investigated, and the largest colonisable surface area compared to the many other springs included in the CRENODAT Project. CRENODAT and several other spring-habitat projects carried out in the Alps and in the northern Apennines (MC unpublished data) al- 
Table 3. Absence of significant multiple regressions between selected biotic and abiotic parameters for Hildenbrandia rivularis [(D.W.) Dry weight; (L.O.I.)Loss On Ignition organic matter; (Pheo) Pheophytin; (Beta) standardized regression coefficient; (SE) standard error, (t) t statistic].

\section{Hildenbrandia rivularis}

\begin{tabular}{|c|c|c|c|c|}
\hline D.W. & Beta & SE & $\mathrm{t}(19)$ & $\mathrm{P}$ \\
\hline Intercept & & & 1.7076 & 0.1040 \\
\hline shading & -0.0045 & 0.2291 & -0.0196 & 0.9845 \\
\hline current vel. & -0.0496 & 0.2291 & -0.2163 & 0.8310 \\
\hline L.O.I. & Beta & SE & $\mathrm{t}(19)$ & $\mathrm{P}$ \\
\hline Intercept & & & 0.4747 & 0.6404 \\
\hline shading & 0.1616 & 0.2216 & 0.7291 & 0.4748 \\
\hline current vel. & 0.2033 & 0.2216 & 0.9174 & 0.3704 \\
\hline Chl-a & Beta & SE & $\mathrm{t}(19)$ & $\mathrm{P}$ \\
\hline Intercept & & & 1.4006 & 0.1775 \\
\hline shading & 0.0546 & 0.2291 & 0.2383 & 0.8142 \\
\hline current vel. & 0.0090 & 0.2291 & 0.0394 & 0.9690 \\
\hline Pheo & Beta & SE & $\mathrm{t}(19)$ & $\mathrm{P}$ \\
\hline Intercept & & & 1.3921 & 0.1800 \\
\hline shading & -0.2856 & 0.2188 & -1.3049 & 0.2075 \\
\hline current vel. & 0.0901 & 0.2188 & 0.4118 & 0.6851 \\
\hline
\end{tabular}

Table 4. Coefficients of variation (CV), standard deviations (DS), and averages for ecophysiological variables considered for the two macroalgal species [(D.W.) Dry weight; (L.O.I.) Loss On Ignition organic matter; (Pheo) Pheophytin, (Fucox) Fucoxanthin].

\begin{tabular}{crrr}
\hline H. rivularis & \multicolumn{1}{c}{ mean } & \multicolumn{1}{l}{ SD } & \multicolumn{1}{c}{ CV } \\
\hline D.W. & 5.48 & 3.83 & 69.9 \\
L.O.I. & 2.05 & 1.42 & 69 \\
Chl- $a$ & 2.9 & 1.95 & 70 \\
Pheo & 0.45 & 0.6 & 132.6 \\
& & & \\
\hline H. foetidus & mean & \multicolumn{1}{c}{ SD } & \multicolumn{1}{c}{ CV } \\
\hline D.W. & 4.28 & 2.1 & 49 \\
L.O.I. & 3.64 & 2.04 & 56 \\
Chl- $a$ & 34.9 & 19.26 & 55.2 \\
Fucox & 12.86 & 7.22 & 56.2 \\
\hline
\end{tabular}

lowed to carry out qualitative observations on the macroscopic patterns and sometimes also seasonal features of $H$. rivularis and $H$. foetidus. These observations are consistent with the results of the present study, supporting the assumption that two representative spring environments were chosen.

By comparing the relative changes of ecophysi- ological parameters of the two macroalgae it emerges that $H$. rivularis surprisingly shows greater variability than $H$. foetidus. This result must however take into account the limits of the sampling carried out and the fact that the two algae live in different sites and are therefore subjected to different abiotic variables during the course of the year. For example, the degree of shading varies a lot, seasonally, in Tovare, whilst in Cambiali it remains almost constant.

In conclusion, this study provided examples of strategies through which two species of macroalgae have adapted their seasonal development to the peculiar physical and chemical settings of springs, and showed that the extent of seasonal fluctuations in algal ecophysiological traits can vary markedly.

\section{ACKNOWLEDGements}

The present study was carried out within the CRENODAT Project (Biodiversity Assessment and Integrity Evaluation of Springs of Trentino -Italian Alps- and Long-term Ecological Research, 20042007). We are grateful to Dr. Juri Nascimbene for the identification of the aquatic lichens of the Tovare Spring.

\section{REFERENCES}

Blinn D.W.; Fredericksen A. \& Korte V. (1980): Colonization rates and community structure of diatoms on three different rock substrata in a lotic system. - British Phycological Journal 15: 303-310.

Bourrelly P. (1955): Quelques stations françaises d'Hildenbrandia rivularis (Liebm.) Bréb. - Rev. Algol. 1: 168-169.

Cantonati M.; Bertuzzi E.; Scalfi A. \& Campana V. (2009): The potential importance for spring conservation of residual habitats after flow capturing: A case study. Verh. Internat. Verein. Limnol. 30: 1267-1270.

Cantonati M.; Füreder L.; Gerecke R.; Jüttner I. \& Cox E.J. (2012a.): Crenic habitats, hotspots for freshwater biodiversity conservation: toward an understanding of their ecology. - Freshwater Science 31: 463-480.

Cantonati M.; Rott E.; Spitale D.; Angeli N. \& Komárek J. (2012b): Are benthic algae related to spring types? Freshwater Science 31: 481-498.

Cazaubon, A. (1989): La florule epiphyte - principalement diatomique - de diverses plantes-hotes a la source d'une rivière méditerranéenne (L'Argens, sud-est de la France). - Cryptogamie Algol. 10: 195-207.

Ceschin, S.; Ricci, S.; Abati, S.; Bisceglie, S.; Minciardi, M.R. \& Zuccarello, V. (2013): Distribution and ecology of red algae in Italian rivers. - Fundamental and Applied Limnology 183: 223-237. 10.1127/18639135/2013/0493

Cox, E.J. (1990): Studies on the algae of a small softwater stream. II. Algal standing crop (measured by chlorophyll-a) on soft and hard substrata. - Arch. Hydrobiol. 4: 553-566.

Eloranta, P. \& Kwandrans, J. (2004): Indicator value of freshwater red algae in running waters for water quality assessment. - Oceanol. Hydrobiol. Stud. 33: $47-54$.

Elwood, J.W.; Newbold, J.D.; Trimble, A.F. \& Stark, R.W. 
(1981): The limiting role of phosporus in a woodland stream ecosystem: effects of P enrichment on leaf decomposition and primary producers. - Ecology 62: 146-158.

Frassanito, R.; Cantonati, M.; Tardìo, M.; Mancini, I. \& Guella, G. (2005): On-line identification of secondary metabolites in freshwater microalgae and cyanobacteria by combined liquid chromatographyphotodiode array detection-mass spectrometric techniques. - Journal of Chromatography A 1082: 33-42.

Gerecke, R.; Cantonati, M.; Spitale, D.; Stur, E. \& WiedenBRUG, S. (2011): The challenges of long-term ecological research in springs in the northern and southern Alps: indicator groups, habitat diversity, and medium term change. - Journal of Limnology 70(Suppl. 1): 168-187.

Gutowski, A. \& Foerster, J. (2009): Benthische Algen, ohne Diatomeen und Characeen. Bestimmungshilfe. LANUV-Arbeitsblätter 2 \& 9. - 474 pp., LANUV NRW Ed.

Hill, W.R.; Ryon, M.G. \& Schilling, E.M. (1995): Light limitation in a stream ecosystem: responses by primary producers and consumers. - Ecology 76: 1297-1309.

Jakubas, E.; GĄBKA, M. \& JoniaK, T. (2014): Factors determining the distribution of rheophil and protected Hildenbrandia rivularis (Liebman) J. Agardh 1851, the Rhodophyta freshwater species in lowland ecosystems.- Polish Journal of Ecology 62: 679-693.

King, L.; Clarke, G.; Bennion, H.; Kelly, M.G. \& Yallop, M. (2006): Recommendations for sampling littoral diatoms in lakes for ecological status assessments. J. Appl. Phycol. 18: 15-25.

Knappe, J.; Geissler, U.; Gutowski, A. \& Friedrich, G. (1996): Rote Liste der limnischen Braunalgen (Fucophyceae) und Rotalgen (Rhodophyceae) Deutschlands. - Schriftenreihe für Vegetationskunde 28: 609-623.

Kremer, B.P. (1983): Untersuchungen zur Ökophysiologie einiger Süsswasserrotalgen. - Decheniana 136: $31-42$.

Kristianen, J. (2005): Golden Algae: A Biology of Chrysophytes. -167 pp., Germany: Koeltz Scientific Books.

Leukart, P. \& Hanelt, D. (1995): Light requirements for photosynthesis and growth in several macroalgae from a small soft-water stream in the Spessart Mountains, Germany. - Phycologia 34: 528-32.

Lindstrøm, E.A.; Johansen, S.W. \& Saloranta, T. (2004): Periphyton in running waters - long-tern studies of natural variation. - Hydrobiologia 521: 63-86.

LORENZEN, C.J. (1967): Determination of chlorophyll and pheopigments: spectrophotometric equations. - Limnol. Oceanogr. 12: 543-546.

Marker, A.F.; Nusch, E.A.; Rai, H. \& Riemann, B. (1980): The measurement of photosynthetic pigments in freshwaters and standardization of methods: conclusion recommendation. - Arch. Hydrobiol. Beih. Ergebn. Limnol. 14: 91-106.

Maurice, C.G.; Lowe, R.L.; Burton, T.M. \& Stanford, R.M. (1987): Biomass and compositional changes in the periphytic community of an artificial stream in response to lowered $\mathrm{pH}$. - Water, Air and Soil Pollution. 33: 165-177.

NeCCHI, O.JR. \& ZUCCHI, M.R. (2001): Photsynthetic performance of freshwater Rodophyta in response to temparature, irradiance, $\mathrm{pH}$ and diurnal rhythm. - Phy- col. Res. 49: 305-318.

Nicholls, K.H. \& WuJeK, D.E. (2002): Chrysphycean Algae. - In: Wehr, J.D. \& Sheath, R.G. (ed.): Freshwater Algae of North America: Ecology and Classification. - pp. 471-510, USA: Academic Press.

Nichols, H.W. (1965): Culture and development of Hildenbrandia rivularis from Denmark and North America. - Amer. Jour. Bot. 52: 9-15.

ORANGe, A. (2000): Verrucaria Schrader (freshwater species). - In: Seaward, M.R.D. (ed.): Lichen Atlas of British Isles, Fascicle 5. - British Lichen Society, London.

Peterson, C.G. \& Stevenson, R.J. (1992): Resistance and resilience of lotic algal communities: importance of disturbance timing and current. - Ecology 73: 14451461.

Pfister, P. (1993): Seasonality of macroalgal distribution patterns within the reach of a gravel stream (Isar, Tyrol, Austria). - Arch. Hydrobiol. 129: 89-107.

Ros, M.D.; Jimenez, E.L. \& ABoAL, M. (1997): Notas Breves. Primera cita de Hildenbrandia angolensis Welwitsch ex West W, \& West WS (Hildenbrandiales, Rodophyceae), para la flora algal epicontinental espanola. Anales Jardin botanico de Madrid. 55: 458-460.

Rott, E.; Walser, L. \& Kegele, M. (2000): Ecophysiological aspects of macroalgal seasonality in a gravel stream in the Alps (River Isar, Austria). - Verh. Internat. Verein. Limnol. 27: 1622-1625.

Rott E., Cantonati M., Füreder L. \& P. Pfister (2006a): Benthic algae in high altitude streams of the Alps - a neglected component of aquatic biota. Hydrobiologia 562: 195-216.

Rott, E.; Füreder, L.; Schütz, C.; Sonntag, B. \& Wille, A. (2006b). A conceptual model for niche differentiation of biota within an extreme stream microhabitat. -Verh. Internat. Verein. Limnol. 29: 2321-2323.

Rott, E.; Van Dam, H.; Pfister, P.; Pipp, E.; Pall, K.; BinDER, N. \& OrtLER, K. (1999): Indikationslisten für Aufwuchsalgen. Teil 2: Trophieindikation, geochemische Reaktion, toxikologische und taxonomische Anmerkungen. - Publ. Wasserwirtschaftskataster, BMfLF: $1-248$.

Roy, J.W.; Zaitlin, B.; Hayashi, M. \& Watson, S.B. (2011): Influence of groundwater spring discharge on smallscale spatial variation of an alpine stream ecosystem. - Ecohydrology 4: 661-670. doi:10.1002/eco.156

Sabater, S.; Aboal, M. \& Cambra, J. (1989): Nuevas observaciones de Rodofíceas en aguas epicontinentales del NE y SE de España. - Limnética 5: 93 -100.

SheAth, R.G. (2003): Red algae. - In: Wehr, J.D. \& Sheath, R.G. (eds): Freshwater Algae of North America. pp. 197-223, Academic Press, New York .

Sheath, R.G. \& Burkholder, J. (1985): Characteristics of softwater stream in Rhode Island. II: Composition and seasonal dynamics of macroalgae communities. - Hydrobiologia 128: 109-118.

SheAth, R.G. \& Hambrook, J.A. (1990): Freshwater ecology. - In: Cole, K.M. \& Sheath, R.G. (eds): Biology of the Red Algae. - pp. 423-453, Cambridge University Press, Cambridge.

Sheath, R.G.; KaczmarczyK, D. \& Cole, K.M. (1993): Distribution and systematics of freshwater Hildenbrandia (Rhodophyta, Hildenbrandiales) in North America. - Eur. J. Phycol. 28: 115-121.

Sherwood, A.R. \& ShaEth, R.G. (1999): Seasonality of mac- 
roalgae and epilithic diatoms in spring-fed streams in Texas, USA. - Hydrobiologia 390: 73-82.

Sherwood, A.R. \& Sheath, R.G. (2000): Microscopic analysis and seasonality of gemma production in the freshwater red alga Hildenbrandia angolensis (Hildenbrandiales, Rhodophyta). - Phycol. Res. 48: 241-249.

Sherwood, A.R.; Troina, B.S. \& Sheath, R.G. (2002): European freshwater Hildenbrandia (Hildenbrandiales, Rhodophyta) has not been derived from multiple invasion from marine habitats. - Phycologia. 41: 87-95.

Sherwood, A.R. \& Sheath, R.G. (2003): Systematics of the Hildenbrandiales (Rodophyta): gene sequence and morphometric analyses of global collections. - J. Phycol. 39: 409-422.

Spitale, D.; Lencioni, V. \& Cantonati, M. (2012): Relative importance of space and time in determining the biotic structure in the upper part of spring-fed streams. -Freshw. Sci. 31: 586-598.

Stanford, J.A.; Ward, J.V. \& Ellis, B.K. (1994): Ecology of the alluvial aquifers of the athead river, Montana (USA). - In: Gibert, J.; Danielopol, D.L. \& StanFORD, J. (eds): Groundwater Ecology. - pp. 367-390, Academic Press. London.

Starmach, K. (1969): Growth of thalli and reproduction of the red alga Hildenbrandia rivularis (Liebm.) J. Ag. - Acta Soc. Bot. Polon. 38: 523-533.

TAXböCK, L.; Linder, H.P. \& CANTOnati, M. (2016): To what extent are Swiss springs refugial habitats for sensitive and endangered diatom taxa? - Aquatic Conservation, submitted.

Teal, J.M. (1957): Community metabolism in a temperate cold spring - Ecol. Monogr. 27:283-302.
Tranen, T.S. \& Lindstrøm, E.A. (1983): Influence of current velocity on periphyton distribution. - In: Wetzel, R.G. (ed.): Periphyton of Freshwater Ecosystems V. - pp. 97-99, Dr W Junk Publishers, Boston.

Uehlinger, U.; Zah, R. \& Burgi, H.R. (1998): The Val Roseg project: temporal and spatial pattern of benthic algae in an alpine stream ecosystem influenced by glacier runoff. - In: Kovar, K.; Tappeiner, U.; Petts, N.E. \& Craig, R.G. (eds): Hydrology, Water Resources and Ecology in Headwaters. - Wallingford International Association of Hydrological Sciences 248: 419-424.

Vannote, R.L.; Minshall, G.W.; Cummins, K.W.; Sedell, J.R. \& Cushing, C.E. (1980): The river continuum concept. - Canadian Journal of Fisheries and Aquatic Sciences 37: 130-137.

WARD, J.V. \& Dufford, R.G. (1979): Longitudinal and seasonal distribution of macroinvertebrates and epilithic algae in a Colorado springbrook-pond system. Arch. Hydrobiol. 86: 284-321.

WeHr, J.D. (1981): Analysis of seasonal succession of attached algae in a mountain stream, the North Alouette River, British Columbia. - Can. J. Botany 59: $1465-1474$

Wyatt, K.H.; Hauer, F.R. \& Pessoney, G.F. (2008): Benthic algal response to hyporheic-surface water exchange in an alluvial river. - Hydrobiologia 607: 151-161.

Żelazna-WieczoreK, J. \& Ziulkiewicz, M. (2008): Hildenbrandia rivularis (Rhodophyta) in central Poland. Acta Soc. Bot. Pol. 77: 41-47.

(C) Czech Phycological Society (2016)

Received October 10, 2015

Accepted December 21, 2015 